\title{
Key to Brief Citations
}

C E. K. Chambers, The Elizabethan Stage, 4 vols. (Oxford University Press, 1923)

ODNB Oxford Dictionary of National Biography, ed.

H. C. G. Matthew and Brian Harrison (Oxford University Press, 2004)

E Elizabeth I: Collected Works, ed. Leah S. Marcus, Janel Mueller, and Mary Beth Rose (University of Chicago Press, 1964)

FQ Edmund Spenser, The Faerie Queene (Penguin Books, 1978)

IC Inns of Court, Records of Early English Drama, ed. Alan H. Nelson and John R. Elliott, Jr., 3 vols.

(D. S. Brewer, 20I0)

SE The Spenser Encyclopedia, ed. A. C. Hamilton et al. (University of Toronto Press, I990)

Note: The spelling and punctuation of quotations from Renaissance texts have been modernized for ease of reading. 
This page intentionally left blank 